\title{
Anthropogenic droughts are expected to exacerbate water inequalities in postcolonial cities
}

\section{Maria Rusca ( $\nabla$ maria.rusca@manchester.ac.uk)}

The University of Manchester https://orcid.org/0000-0003-4513-3213

\section{Elisa Savelli}

Uppsala Univerrsity https://orcid.org/0000-0002-8948-0316

\section{Giuliano Di Baldassarre}

Uppsala University https://orcid.org/0000-0002-8180-4996

\section{Adriano Biza}

IHE Delft

\section{Gabriele Messori}

Department of Earth Sciences, Uppsala University, Uppsala, Sweden

\section{Analysis}

Keywords: climate change, equitable urban development, anthropogenic droughts, water inequalities

Posted Date: November 24th, 2021

DOI: https://doi.org/10.21203/rs.3.rs-1072145/v1

License: (c) (1) This work is licensed under a Creative Commons Attribution 4.0 International License. Read Full License 


\section{Title page}

2
3

4 Anthropogenic droughts are expected to exacerbate water inequalities 5 in postcolonial cities

6
7

Maria Rusca $^{\mathrm{a}^{*}}$, Elisa Savelli ${ }^{\mathrm{b}, \mathrm{c}}$, Giuliano Di Baldassarre ${ }^{\mathrm{b}, \mathrm{c}}$, Adriano Biza ${ }^{\mathrm{d}}$, Gabriele Messorib ${ }^{\mathrm{b}, \mathrm{e}, \mathrm{f}}$

maria.rusca@manchester.ac.uk

$12{ }^{a}$ School of Environment, Education and Development, Global Development Institute

$13{ }^{\mathrm{b}}$ Department of Earth Sciences, Air, Water and Landscape Science, Uppsala University, 75236 Uppsala, Sweden;

$14{ }^{\mathrm{c}}$ Centre of Natural Hazards and Disaster Science, CNDS, 75236 Uppsala, Sweden;

$15{ }^{\mathrm{d}}$ IHE-Delft,

$16{ }^{\mathrm{e}}$ Department of Meteorology, Stockholm University, 10691 Stockholm, Sweden;

$17{ }^{\mathrm{f}}$ Bolin Centre for Climate Research, 10691 Stockholm, Sweden.

18

19 


\section{Anthropogenic droughts are expected to exacerbate water inequalities 21 in postcolonial cities}

23 Abstract

24 There are growing concerns about the impacts of climate change on equitable urban 25 development. As cities are becoming increasingly exposed to anthropogenic droughts, stakes

26 are particularly high in contexts of severe vulnerability. Yet, the impacts of future urban

27 droughts and the societal responses they will elicit remain poorly understood. Here we

28 develop social-environmental scenarios of anthropogenic drought-related impacts in

29 postcolonial cities, characterized by highly uneven development and differentiated levels of

30 vulnerability. We show how unprecedented droughts are expected to polarize existing

31 inequalities in water access and well-being across genders, race and socio-economic groups.

32 Specifically, unprecedented droughts will likely exacerbate spatial inequalities, generate

33 localized public health crises, and regress development progress in water access. These

34 results suggest that effective climate policies must address water insecurity and other pre-

35 existing inequalities, and develop equitable water conservation measures to ensure effective 36 adaptation to future unprecedented extreme droughts.

\section{Main text}

40 Anthropogenic climate change, urbanization, deforestation, and/or large water infrastructure

41 have intensified the severity of recent droughts in several regions, including Brazil ${ }^{1}$,

42 California $^{2,3}$ China $^{4,5}$, Spain $^{6}$, and Southern Africa ${ }^{7}$. These regions are therefore at risk of

43 experiencing future droughts that are unprecedented in the historical record. At the same

44 time, the rapid urban growth of the past two decades, much of which has occurred and 
45 continues to occur in the Global South, is placing cities under significant risk of water stress ${ }^{8}$.

46 Human water consumption has exceeded renewable freshwater resources in many parts of the

47 world ${ }^{9,10}$ Consequently, drought events often lead to severe socio-economic losses and water

48 shortages ${ }^{11,12}$. Today, urban droughts pose a key challenge to the achievement of the United

49 Nations' Sustainable Development Goals ${ }^{13}$ and, as stated in a recent Nature Sustainability

50 editorial $^{14}$, "every world city should prepare [to droughts] before it's too late".

51 Many cities have been close to experiencing or have experienced a countdown to 'Day Zero'

52 - the day in which a city will be unable to supply water to its residents. Cape Town (South

53 Africa) has recently captured public attention worldwide, and Chennai (India), São Paulo

54 (Brazil), and Istanbul and several other cities in Turkey have undergone or are undergoing

55 similar water crises ${ }^{15-17}$. This underscores the urgency of exploring how future, unprecedented drought events may impact urban populations and what societal responses they might elicit. Here, we seek to address this major scientific gap. Our primary focus in this paper is to analyze how post-colonial cities in the Global South are responding and might respond to unprecedented droughts. Urban droughts are particularly concerning in post-

60 colonial cities, where splintered infrastructures are the norm ${ }^{18}$. In stark contrast with the

61 'modern infrastructural ideal' envisaging universal standardized services and networked

62 infrastructures ${ }^{19}$, since colonial times cities in the global South are characterized by stark

63 inequalities in water and sanitation (in)security across urban spaces ${ }^{18,20,21}$. According to a

64 recent World Bank report, water utilities in sub-Saharan Africa only reach, on average, sixty

65 percent of the urban population ${ }^{22}$. Moreover, whilst there is a tendency to consider urban

66 inequalities as a split between connected and unconnected residents, recent research on

67 Global South cities has exposed differentiated levels of water (in)security within centralized

68 water supply networks ${ }^{23-25}$. Crucially, understanding why some urban dwellers are

69 disproportionately more vulnerable to droughts than others is essential to reduce drought risk 
70 both today and in the future. Numerous approaches and frameworks have been recently 71 developed in the attempt to further theorization and predictions of drought events and other

72 extremes $^{26-31}$. These approaches, however, largely overlook the role of power and politics,

73 the heterogeneity of society, and variability in the exercise of agency of different social

74 groups and individuals. This prevents a comprehensive understanding of the complex

75 feedback between society and droughts generating extreme events and the uneven

76 distribution of negative impacts ${ }^{32,33}$. Here, we implement a framework termed Social-

77 Environmental Extremes Scenario Approach (SEEA, see Figure 1) ${ }^{33}$.

78 This approach expands the reductionist hydroclimatic conceptualization of water scarcity by

79 integrating analyses of how power, differentiated agency, economic development and policy

80 visions shape drought phenomena, risk accumulation, and differentiated vulnerability and

81 recovery trajectories. We specifically develop a combined qualitative and quantitative

82 assessment to build a scenario of human responses to unprecedented droughts in Maputo,

83 Mozambique. Fast growing cities in low-income African countries with high levels of socio-

84 economic inequalities, limited water supply infrastructure and inadequate services, such as

85 Maputo, provide a case-in-point of the threat that urban droughts pose to water security in

86 postcolonial cities. We build our scenario based on four pillars: critical social sciences

87 theories on societal responses to urban droughts (Pillar 1; Figure 2 and Table S1); historical

88 climate data and regional numerical climate projections (Pillar 2); socio-economic responses

89 to past droughts at the location of interest (here the 2015-2017 drought in Maputo, Pillar 3);

90 and a conceptual transfer to future unprecedented droughts at the location of interest from

91 past droughts at other locations (here the 2015-2017 drought in Cape Town, which was of

92 greater magnitude than any drought in Maputo in recent history, Pillar 4). The aim of this

93 framework is not to make a deterministic forecast, but rather to build a story-line highlighting

94 criticalities from a sustainability and social justice perspective. 
96 For Pillar 2, we note that Mozambique ranks amongst the world's most vulnerable countries

97 to climate change ${ }^{34}$ and has experienced repeated severe droughts in recent decades ${ }^{35}$, which

98 have been especially frequent in the central and southern parts of the country ${ }^{36}$. These

99 extreme events have occurred on the background of a multi-decadal drying trend (e.g. ${ }^{37}$ ).

100 Focusing on the Southern part of the country, where Maputo is located, the latest generation

101 of global climate models points to a future aggravation of the regional risk of extreme

102 meteorological and agricultural drought conditions ${ }^{38}$. Regional climate simulations using

103 precipitation and evapotranspiration jointly to diagnose drought, support these conclusions ${ }^{39}$.

104 There are large uncertainties in future climate projections of precipitation, and diagnosing

105 drought often requires considering additional variables - such as evapotranspiration - which

106 bear their own uncertainties. Nonetheless, the ongoing climate trends and numerical

107 projections of future climates all point to the possibility that Southern Mozambique may be

108 affected by a future, unprecedented drought with a higher likelihood than one may expect

109 from a statistical analysis of historical data series. Moreover, Maputo and its surroundings

110 have emerged as a regional drought hotspot over the last several decades (see Methods).

111 Based on the above, we argue for the relevance of an unprecedented drought scenario in

112 Maputo.

113

\section{Colonial legacy shapes drought vulnerability}

115 The theoretical synthesis (Pillar 1), coupled with empirical work in Maputo (Pillar 3) and

116 Cape Town (Pillar 4), points to levels of chronic water (in)security experienced before the

117 unprecedented drought event as the main predictor of vulnerability. Differentiated levels of

118 water (in)security are a legacy of the colonial era ${ }^{16,40-42}$, and attempts to revert this legacy

119 have met with limited success ${ }^{43}$. Maputo is an exemplary expression of the nexus between 
race, class, variegated citizenship, heterogeneous infrastructure and vulnerability

121 conceptualized by critical scholars (Pillar 1). Colonial Maputo was grounded on principles of

122 racial segregation that generated spatial, economic and social inequalities. Due to this

123 heritage, processes of marginalization and dispossession from basic services persist to date.

124 Housing and sanitation policies continue to marginalize lower-income groups, which suffer

125 the most from significant infrastructural deficits and absence of property rights ${ }^{41,44-47}$.

126 Service configurations reflect these uneven developments (Figure 2a). The water utility

127 Águas de Região de Maputo (AdeRM), which relies on surface water from the Umbelúzi

128 river, stored in the Pequenos Libombos dam, has for decades focused on serving higher

129 income residents in the so-called cement city. Whilst water coverage has significantly

130 increased over the past decade ${ }^{48}$, reaching approximately $63 \%$ of the city ${ }^{47}$, quality of the

131 service varies across neighborhoods. Recently developed outer peri-urban areas, inhabited by

132 middle income residents, are primarily supplied by over 800 highly-skilled, small-scale

133 private operators that undertook large investment to develop decentralised networks that

134 increasingly mimic the formal water utility ${ }^{49,50}$. These are regulated by the government, who

135 controls rates of groundwater abstraction, water quality and pricing regimes ${ }^{51}$. In contrast, the

136 poorer urban belt neighborhoods rely on self-supply, household water resales or the formal

137 water utility, which is often unable to deliver the same quality of service offered to

138 neighborhoods in the city center ${ }^{48}$.

139 The sanitation landscape is even more unequal. A minority of the population ( 9 percent)

140 enjoys publicly managed, supply-driven sanitation services; the middle class relies on pour-

141 flush toilets with septic tanks (49 percent), and low-income residents make do with

142 unimproved or improved pit latrines (41 percent) or (approximately 1 percent) practice open

143 defecation ${ }^{52}$. New investments in wastewater infrastructures ${ }^{53}$ are targeting rehabilitation and

144 upgrading of the sewerage systems and the treatment facility, thereby reproducing 
existing infrastructural inequalities and the segregationist logic embedded in the sanitation

146 landscape. Present and future drought vulnerability can only be understood in relation to

147 Maputo's urban form and the variegated water and sanitation (in)security levels it generates.

\section{Polarized urban inequalities and public health crises from anthropogenic droughts}

150 A synergistic application of the SEEA suggests that an unprecedented drought in Maputo

151 could significantly exacerbate existing inequalities. Chronically water insecure households

152 will suffer the most from water shortages, with a cascading effect on other urban inequalities.

153 From Pillar 3 (Precedents in Maputo), we infer that the impact of an unprecedented drought

154 will disproportionately affect residents served by the water utility as compared to areas

155 served by small-scale water providers. Levels of water insecurity are expected to differ across

156 the urban spaces served by the water utility, as water rationing measures are likely to generate

157 longer and more severe water shortages in peripheral neighborhoods at the margins of the

158 water supply network. As noted for other postcolonial cities (Pillar 1, Theoretical Synthesis),

159 the technical specification of the network in Maputo will likely allow higher income

160 neighborhoods located closer to the distribution centers to capture most of the rationed water.

161 Moreover, affluent households are expected to rely on larger storage tanks to buffer rationing

162 measures, whilst mid and lower income residents may only be able to store between 20 and

163250 liters per household and day to cope with restrictions (Pillar 3, Precedents in Maputo).

164 We also expect demand management measures to include tariff increments to reduce

165 consumption, as occurred during the unprecedented drought in Cape Town (Pillar 4,

166 Conceptual transfer) and in other locations (Pillar 1, Theoretical synthesis). This measure will

167 probably affect the behavior of residents that already consume a limited amount of water the

168 most, making them severely water-insecure. In contrast, higher income residents that can 
169 afford higher rates will likely continue to consume at unsustainable rates, thus remaining

170 more water secure.

171 Prolonged water shortages are expected to exacerbate other urban inequalities (Figure 3).

172 From Pillar 1 (Theoretical synthesis) and 3 (Precedents in Maputo) we note that women will

173 likely be disproportionately burdened with the task of finding alternative water sources, with

174 consequences on their employment and income, physical and psychological stress associated

175 with both fetching and not being able to fetch water, and increased risks of violence if

176 sourcing water in the dark or from distant locations. An unprecedented drought might

177 exacerbate food-insecurity of lower income households due to both inflated food prices and

178 the impact of water rationing measures on the ability of lower income residents to maintain

179 their vegetable urban gardens. This, in turn, is expected to increase residents - and

180 particularly women's - vulnerability to widely spread diseases such as $\mathrm{HIV}^{54}$. Last,

181 prolonged shortages will most likely exacerbate water-related health risks and generate

182 unprecedented public health crises, largely concentrated in low-income neighborhoods.

183 Drawing on Pillar 3 (Precedents in Maputo), we infer that outbreaks of waterborne diseases

184 and malaria cases will be concentrated in areas with the most significant infrastructure

185 deficits. Chronic water shortages might force residents to resort to unimproved sources such

186 as river streams or to cut pipes to access water from the mains, thereby increasing risks of re-

187 contaminated drinking water. Low-lying neighborhoods served by pit latrines will likely be

188 the most at risk. These areas are expected to simultaneously experience prolonged water

189 shortages and more frequent flash floods, because drought events reduce the capacity of soil

190 to absorb water. This will probably increase risks of fecal contamination of drinking water

191 sources and, in turn, waterborne diseases. Moreover, storage practices of low-income

192 dwellers relying on uncovered water facilities located near humans, can increase risks of

193 mosquito breeding and, in turn, of vector-borne diseases like dengue and malaria. 


\section{Reversing progress in water access or vicious supply-demand cycle?}

195 Global political economy is expected to significantly shape the Mozambican government's

196 response to the drought, which largely depends on its ability to access global capital. As this

197 outcome is largely unpredictable, we consider a scenario in which the government does not

198 have access to global capital and one of large capital inflows. In the first scenario, the recent

199 corruption and hidden debt scandals ${ }^{55}$ will continue to limit the Mozambican government's

200 access to global capital and the government is unlikely to have the resources to develop large-

201 scale infrastructures to increase supply. Based on Pillar 3 (Precedents in Maputo), we predict

202 that the pressure to manage a limited supply for existing customers will constrain the water

203 utility's ability to expand services to unserved urban populations. The city center, inhabited

204 by high income populations, will likely continue to receive water from the water utility,

205 whilst low-income peri-urban areas served by the water utility will suffer from increasing

206 water shortages. As a result, residents will perform different forms of 'going off the grid': a

207 synergistic application of SEEAs Pillars suggests that those with access to land in areas with

208 high water table and financial resources will opt for developing alternative or additional

209 water sources, including boreholes, larger storage tanks and rain-tanks. Those in proximity of

210 areas served by small scale providers that provide more reliable services will add a second

211 connection to augment water availability for the household, whilst others will have to revert

212 to buying water from communal water points or private boreholes or to rely on unimproved

213 water sources. These coping strategies, alongside rapid urbanization, will reverse progress in

214 water access achieved by the service provider over the past decade and increase

215 fragmentation of services in Maputo. For those who can integrate household water sources,

216 this process will ultimately lead to increased resilience, whilst for those who cannot afford

217 access to safe alternative sources, the process of going off the grid will lead to increased

218 vulnerability. 
219 In an alternative scenario, access to global capital will allow the government to implement its

220 10-years Capital Investment Program aimed at enhancing water security and resilience to

221 climate change by expanding water supplies through the construction of large water

222 infrastructures. Based on Pillars 1 (Theoretical synthesis) and 4 (Conceptual transfer from

223 Cape Town), we suggest that in response to an unprecedented drought, Maputo will enter a

224 vicious cycle of water supply expansion. In the aftermath of a drought event, the water utility

225 and residents will return to 'business as usual' management and consumption practices,

226 characterized by over-allocation to and overconsumption by elites, rather than conservation

227 practices. These practices will be sustained by the increase in water supply, financed through

228 global capital. The government will develop large scale infrastructures that will meet the

229 growing demand and allow to pursue network expansion without addressing inequalities in

230 access and unsustainable consumption patterns. Paradoxically, this increment in water

231 supplies will increase the city's vulnerability to drought events. Development of large water

232 infrastructures will generate a false sense of security, also grounded on the expectation that

233 the city will face droughts of similar intensity to the past, rather than unprecedented in nature.

234 This assumption will lead to increased consumption patterns that in the long term will

235 reproduce water stress conditions and force the government to reactive responses to future

236 drought events.

\section{Intra-urban and inter-national water conflicts}

238 Unprecedented droughts might increase the likelihood of water-related conflicts across intra-

239 urban spaces and water providers, as well as among riparian states. Water shortages will

240 trigger both households and some providers to access new water sources, with risks of

241 overexploitation and increased competition over available water resources. Intra-urban

242 conflicts could be generated by the increased reliance on groundwater resources by the water

243 utility. We note from Pillar 3 (Precedents in Maputo) that the water utility will likely identify 
244 groundwater as the short-term and most affordable solution to cope with the effects of a

245 drought event. Increased reliance on groundwater resources is expected to exacerbate

246 saltwater intrusion in coastal $\operatorname{areas}^{56}$ and, in the longer term, reduce water availability and

247 lower the groundwater table, causing some boreholes to dry up. The reduced quality and

248 quantity of groundwater availability will extend the impact of the water crisis to previously

249 buffered areas, exacerbating the existing tensions among providers relying on this water

250 source. Conflicts with small-scale water providers (SSIPs) are also expected to be

251 exacerbated by the government's plan to expand services to unserved areas, thereby shrinking

252 SSIP market and income.

253 In the past, the assumption that in international river basins characterized by growing water

254 uses or stress, cooperation efforts would prevail over conflicts has held true for the Incomati,

255 Umbeluzi and Maputo rivers ${ }^{57,58}$. However, Mozambique's plans of developing large

256 infrastructures on these basins in combination with a future extreme drought might reduce the

257 ability and willingness of riparian South Africa and Swaziland to reach consensus on water

258 allocation and on how to cope with multiple and conflicting demands. As the Maputo river is

259 less developed in terms of dams and water allocation, tensions are more likely to arise on the

260 Umbeluzi and Incomati river. The Umbeluzi river is currently the source of a large irrigation

261 scheme in Swaziland and of several smallholder farmers in Mozambique. The Incomati river

262 is the selected site for one of the largest dam projects of the Mozambican government. An

263 unprecedented drought could lead to tensions over water allocation and priorities among the

264 three countries.

\section{Conclusions}

266 We developed scenarios of urban droughts in post-colonial cities, characterized by highly unequal development, using the city of Maputo, Mozambique, as a case-in-point. We have 
268 shown that the impact of present and future droughts can only be understood in relation to the

269 colonial history of these cities. The design of the infrastructure, its purposes, and the heritage

270 of the colonial urban form crucially determine what remaining without water - or Day Zero -

271 means for different citizens. As shown by our scenario, spatial and social inequalities,

272 including access to basic services, well-being, gender and socio-economic status generate

273 differential vulnerability to unprecedented extreme droughts. If future policies neglect the

274 heterogeneity of water insecurity and other pre-existing inequalities, only a small part of the

275 urban population will effectively cope with and adapt to future drought events. High levels of

276 vulnerability to droughts are bound to be continuously reproduced or exacerbated if spatial

277 and socio-economic economic inequalities are not addressed. In parallel with this, all actors

278 need to account for the changing physical-environmental context of urban droughts. The

279 ongoing climate change has the potential to lead to large regional hydroclimatic shifts - in the

280 case of Southern Africa towards more drought - prone conditions ${ }^{35,37-39}$. Our scenario is not a

281 deterministic projection, but rather a storyline (or scenario-based) evaluation seeking to

282 identify aspects that are critical in responding to future drought events. However, it allows to

283 us to conclude that more optimistic scenarios are only possible if multiple dimensions of

284 urban inequalities are addressed before the next Day Zero, whilst also abandoning the

285 assumption that future droughts will be similar in scale to those experienced in the past.

286

287 
289 1. Loon, A. F. V. et al. Drought in the Anthropocene. Nature Geoscience 9, 89-91 (2016).

290 2. Diffenbaugh, N. S., Swain, D. L. \& Touma, D. Anthropogenic warming has increased 291 drought risk in California. PNAS 112, 3931-3936 (2015).

292 3. AghaKouchak, A., Feldman, D., Hoerling, M., Huxman, T. \& Lund, J. Water and climate: Recognize anthropogenic drought. Nature News 524, 409 (2015).

4. Qiu, J. China drought highlights future climate threats. Nature 465, 142-143 (2010).

5. Xu, K. et al. Spatio-temporal variation of drought in China during 1961-2012: A climatic perspective. Journal of Hydrology 526, 253-264 (2015).

6. Van Loon, A. F. \& Van Lanen, H. a. J. Making the distinction between water scarcity and drought using an observation-modeling framework. Water Resources Research 49, 1483$1502(2013)$.

7. Yuan, X., Wang, L. \& Wood, E. F. Anthropogenic intensification of southern African flash droughts as exemplified by the 2015/16 season. Herring, SC, N. Christidis, A. Hoell, JP Kossin, CJ Schreck III \& PA Stott, Eds 586-589 (2018).

8. Ray, B. \& Rajib, S. Urban Drought. (Springer, 2019).

9. Gleick, P. H. \& Palaniappan, M. Peak water limits to freshwater withdrawal and use. PNAS 107, 11155-11162 (2010).

10. Vörösmarty, C. J., Green, P., Salisbury, J. \& Lammers, R. B. Global water resources:

308 11. AghaKouchak, A. et al. Anthropogenic Drought: Definition, Challenges, and Opportunities. Reviews of Geophysics 59, e2019RG000683 (2021). Sustainability 1, 617-622 (2018). 
312 13. Zhang, X. et al. Urban drought challenge to 2030 sustainable development goals. Science

313 of The Total Environment 693, 133536 (2019).

314 14. Not a drop to spare. Nat Sustain 1, 151-152 (2018).

315 15. Anandharuban, P. \& Elango, L. Spatio-temporal analysis of rainfall, meteorological

316 drought and response from a water supply reservoir in the megacity of Chennai, India. $J$

$317 \quad$ Earth Syst Sci 130, 17 (2021).

318 16. Millington, N. Producing water scarcity in São Paulo, Brazil: The 2014-2015 water crisis

319 and the binding politics of infrastructure. Political Geography 65, 26-34 (2018).

320 17. NASA. Turkey Experiences Intense Drought.

321 https:/earthobservatory.nasa.gov/images/147811/turkey-experiences-intense-drought

$322 \quad(2021)$

323 18. Ahlers, R., Cleaver, F., Rusca, M. \& Schwartz, K. Informal space in the urban waterscape: Disaggregation and co-production of water services. Water Alternatives 7, 114 (2014).

19. Graham, S. \& Marvin, S. Splintering urbanism: networked infrastructures, technological mobilities and the urban condition. (Psychology Press, 2001).

20. Kooy, M. \& Bakker, K. Technologies of government: Constituting subjectivities, spaces, and infrastructures in colonial and contemporary Jakarta. International Journal of Urban and Regional Research 32, 375-391 (2008).

21. WHO/UNICEF. Progress on household drinking water, sanitation and hygiene 20002017: Special focus on inequalities. vol. 1 (United Nations Children's Fund (UNICEF) and World Health Organization, 2019).

334 22. van den Berg, C. \& Danilenko, A. Performance of Water Utilities in Africa. (World 335 Bank, Washington, DC, 2017). doi:10.1596/26186. 
23. Anand, N. Municipal disconnect: On abject water and its urban infrastructures. Ethnography 13, 487-509 (2012).

24. Björkman, L. Pipe politics, contested waters. (Duke University Press, 2015).

25. Rusca, M., Boakye-Ansah, A. S., Loftus, A., Ferrero, G. \& Van Der Zaag, P. An interdisciplinary political ecology of drinking water quality. Exploring socio-ecological inequalities in Lilongwe's water supply network. Geoforum 84, 138-146 (2017).

26. Balch, J. K. et al. Social-environmental extremes: Rethinking extraordinary events as outcomes of interacting biophysical and social systems. Earth's Future 8,

27. Barnes, M. L. et al. Social determinants of adaptive and transformative responses to climate change. Nature Climate Change 10, 823-828 (2020).

28. Moss, R. H. et al. The next generation of scenarios for climate change research and assessment. Nature 463, 747-756 (2010).

29. O’Neill, B. C. et al. Achievements and needs for the climate change scenario framework. Nature climate change 1-11 (2020).

30. Rao, N. D., van Ruijven, B. J., Riahi, K. \& Bosetti, V. Improving poverty and inequality modelling in climate research. Nature Clim Change 7, 857-862 (2017).

31. Wilson, R. S., Herziger, A., Hamilton, M. \& Brooks, J. S. From incremental to transformative adaptation in individual responses to climate-exacerbated hazards. Nature

32. Castree, N. Changing the Anthropo (s) cene: Geographers, global environmental change and the politics of knowledge. Dialogues in Human Geography 5, 301-316 (2015).

33. Rusca, M., Messori, G. \& Di Baldassarre, G. Scenarios of human responses to unprecedented social-environmental extreme events. Earth's Future 9, e2020EF001911 (2021). 
34. Chen, C. et al. University of Notre Dame global adaptation index country index technical report. ND-GAIN: South Bend, IN, USA (2015).

35. Masih, I., Maskey, S., Mussá, F. E. F. \& Trambauer, P. A review of droughts on the African continent: a geospatial and long-term perspective. Hydrology and Earth System Sciences 18, 3635-3649 (2014).

36. Ministry of Foreign Affairs of the Netherlands. Climate Change Profile: Mozambique. (2018).

37. Dai, A. \& Zhao, T. Uncertainties in historical changes and future projections of drought. Part I: Estimates of historical drought changes. Climatic Change 144, 519-533 (2017).

38. Cook, B. I. et al. Twenty-First Century Drought Projections in the CMIP6 Forcing Scenarios. Earth's Future 8, e2019EF001461 (2020).

39. Abiodun, B. J., Makhanya, N., Petja, B., Abatan, A. A. \& Oguntunde, P. G. Future

40. Anand, N. PRESSURE: The PoliTechnics of Water Supply in Mumbai. Cultural Anthropology 26, 542-564 (2011).

41. Biza, A., Kooy, M., Manuel, S. \& Zwarteveen, M. Sanitary governmentalities: Producing and naturalizing social differentiation in Maputo City, Mozambique (1887-2017). Environment and Planning E: Nature and Space 2514848621996583 (2021) doi:10.1177/2514848621996583.

42. Kimari, W. \& Ernstson, H. Imperial Remains and Imperial Invitations: Centering Race within the Contemporary Large-Scale Infrastructures of East Africa. Antipode 52, 825846 (2020).

43. Myers, G. African cities: alternative visions of urban theory and practice. (Zed Books Ltd., 2011). 
44. Barros, C. P., Chivangue, A. \& Samagaio, A. Urban dynamics in Maputo, Mozambique. Cities 36, 74-82 (2014).

45. Jenkins, P. City profile: Maputo. Cities 17, 207-218 (2000).

46. Roque, S., Mucavele, M. \& Noronha, N. Subúrbios and Cityness: Exploring Imbrications and Urbanity in Maputo, Mozambique. Journal of Southern African Studies 42, 643-658 (2016).

47. Rusca, M. et al. The Urban Metabolism of Waterborne Diseases: Variegated Citizenship, (Waste) Water Flows, and Climatic Variability in Maputo, Mozambique. Annals of the American Association of Geographers 1-20 (2021).

48. Zuin, V. \& Nicholson, M. The Impact of Pro-Poor Reforms on Consumers and the Water Utility in Maputo, Mozambique. Water Alternatives 14, 158-185 (2021).

49. Alda-Vidal, C., Rusca, M., Zwarteveen, M., Schwartz, K. \& Pouw, N. Occupational genders and gendered occupations: the case of water provisioning in Maputo, Mozambique. Gender, Place \& Culture 24, 974-990 (2017).

50. Schwartz, K., Tutusaus Luque, M., Rusca, M. \& Ahlers, R. (In) formality: the meshwork of water service provisioning. Wiley Interdisciplinary Reviews: Water 2, 31-36 (2015).

51. Ahlers, R., Perez Güida, V., Rusca, M. \& Schwartz, K. Unleashing entrepreneurs or controlling unruly providers? The formalisation of small-scale water providers in Greater Maputo, Mozambique. The Journal of Development Studies 49, 470-482 (2013).

52. Hawkins, P. \& Muxímpua, O. Developing business models for fecal sludge management in Maputo. Water and Sanitation Program: Report by International Bank for Reconstruction and Development/The World Bank (2015).

53. WB. Internal Development Association Project on Mozambique Urban Sanitation Project (P161777). (2019). 
410 54. Austin, K. F., Noble, M. D. \& Berndt, V. K. Drying Climates and Gendered Suffering:

411 Links Between Drought, Food Insecurity, and Women's HIV in Less-Developed

412 Countries. Soc Indic Res 154, 313-334 (2021).

413 55. Cortez, E. et al. Costs and consequences of the hidden debt scandal of Mozambique. 142

$414 \quad(2021)$.

415 56. Casillas-Trasvina, A., Zhou, Y., Stigter, T. Y., Mussáa, F. E. F. \& Juízo, D. Application

416 of numerical models to assess multi-source saltwater intrusion under natural and pumping

417 conditions in the Great Maputo aquifer, Mozambique. Hydrogeol J 27, 2973-2992

$418 \quad$ (2019).

419 57. Juízo, D. \& Hjorth, P. Application of a district management approach to Southern

420 African river basin systems: the case of the Umbeluzi, Incomati and Maputo river basins.

$421 \quad$ Water Policy 11, 719-730 (2009).

422 58. van der Zaag, P. \& Carmo Vaz, Á. Sharing the Incomati waters: cooperation and

423 competition in the balance. Water Policy 5, 349-368 (2003).

424 59. World Bank. Greater Maputo: Urban Poverty and Inclusive Growth. World Bank Report.

425 https://openknowledge.worldbank.org/handle/10986/29828 (2017).

426

427 


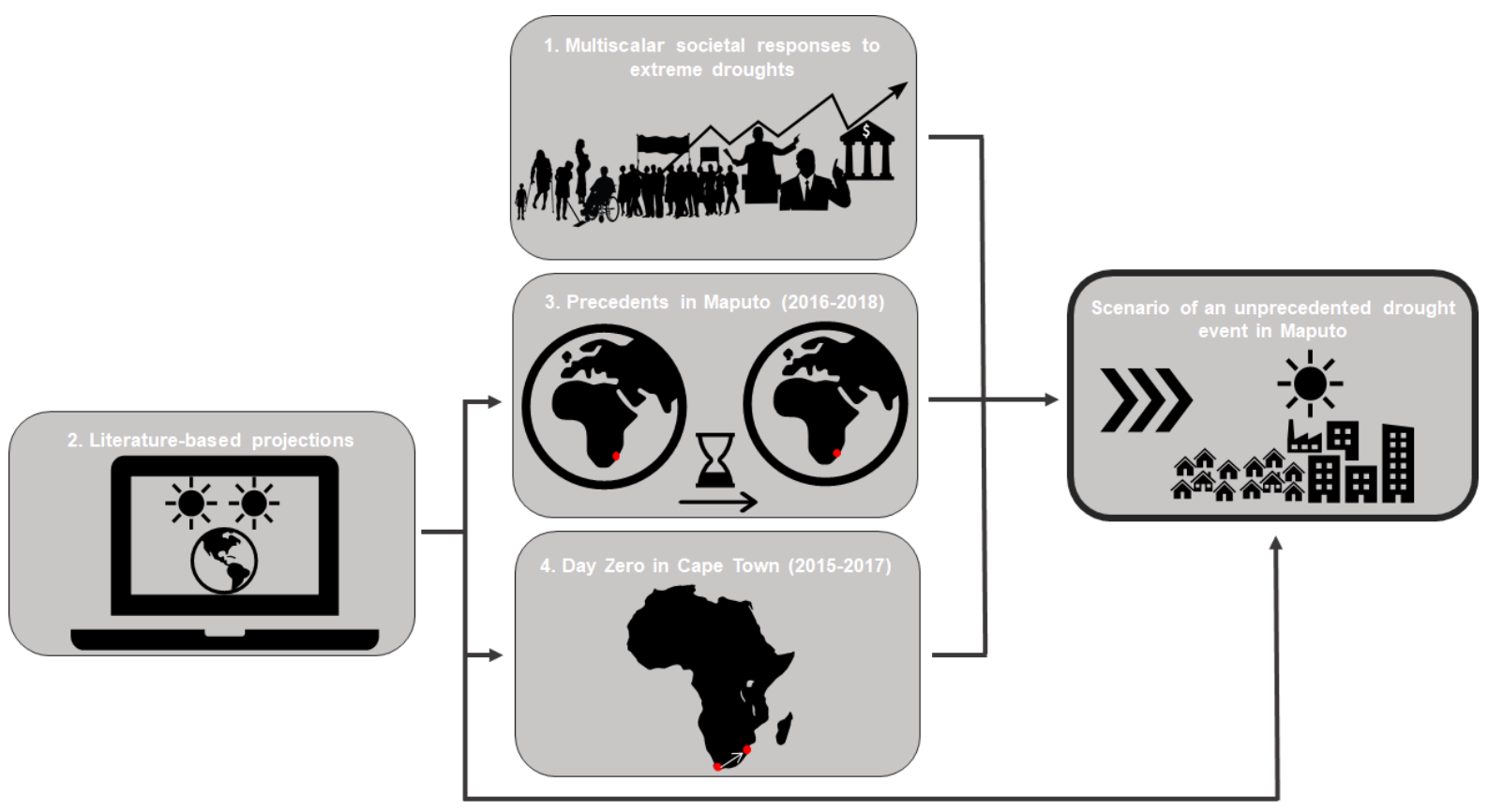

432

433 Figure 1 Schematic of the Social-Environmental Extremes Scenarios Approach for urban droughts.

434 The approach rests on a synergy of literature-based projections of drought conditions in Southern

435 Africa, critical social science theoretical perspectives on societal responses to drought events, and

436 effective use of empirical data from past drought events in Maputo, Mozambique (2016 - 2018) and

437 Cape Town, South Africa (2015-2017).

438 


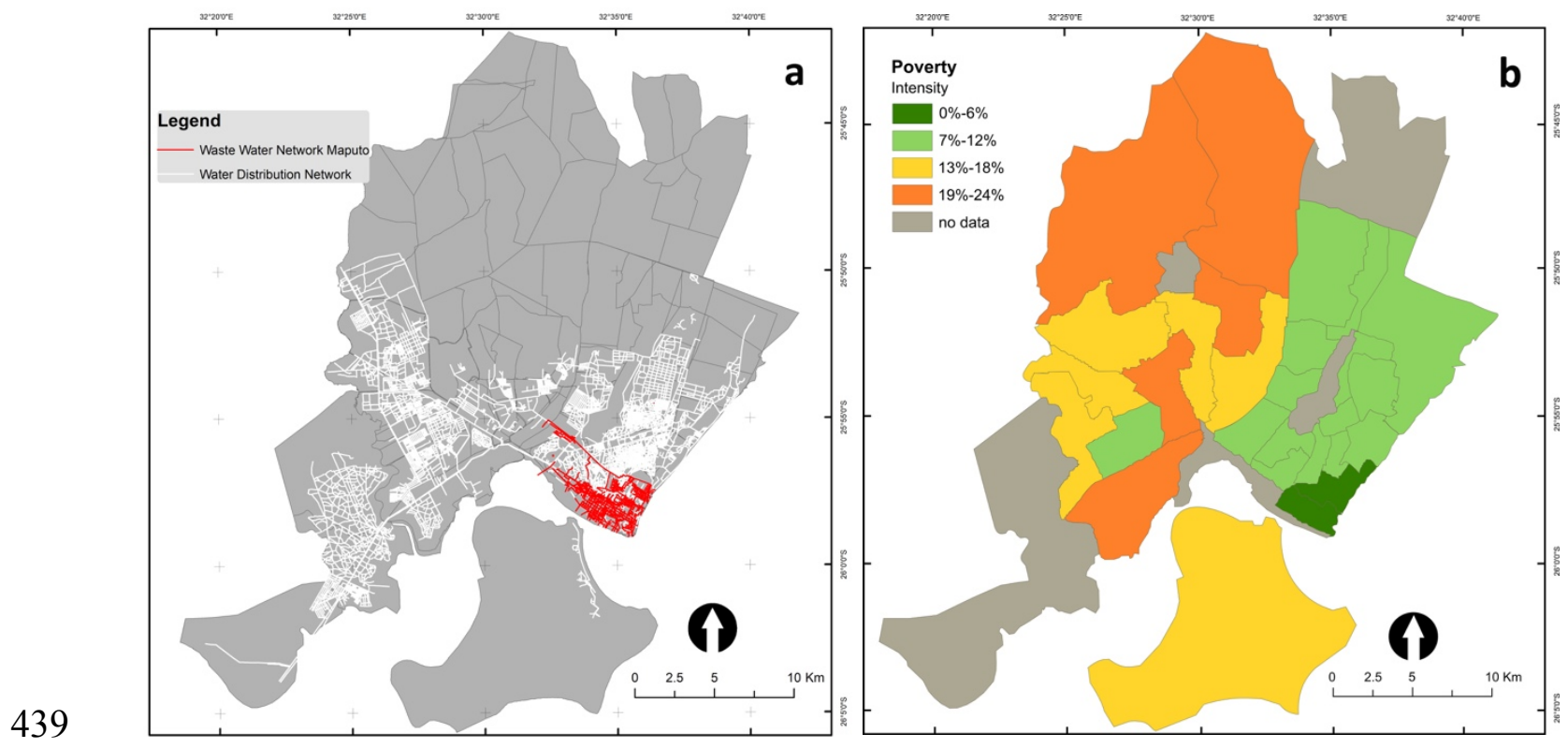

440 Figure 2a Map displaying water sewerage (red) and public water supply network (white) in Greater

441 Maputo. Figure $2 b$ Map displaying poverty intensity of neighborhood in Greater Maputo (Source:

442 World Bank ${ }^{59}$ ). 


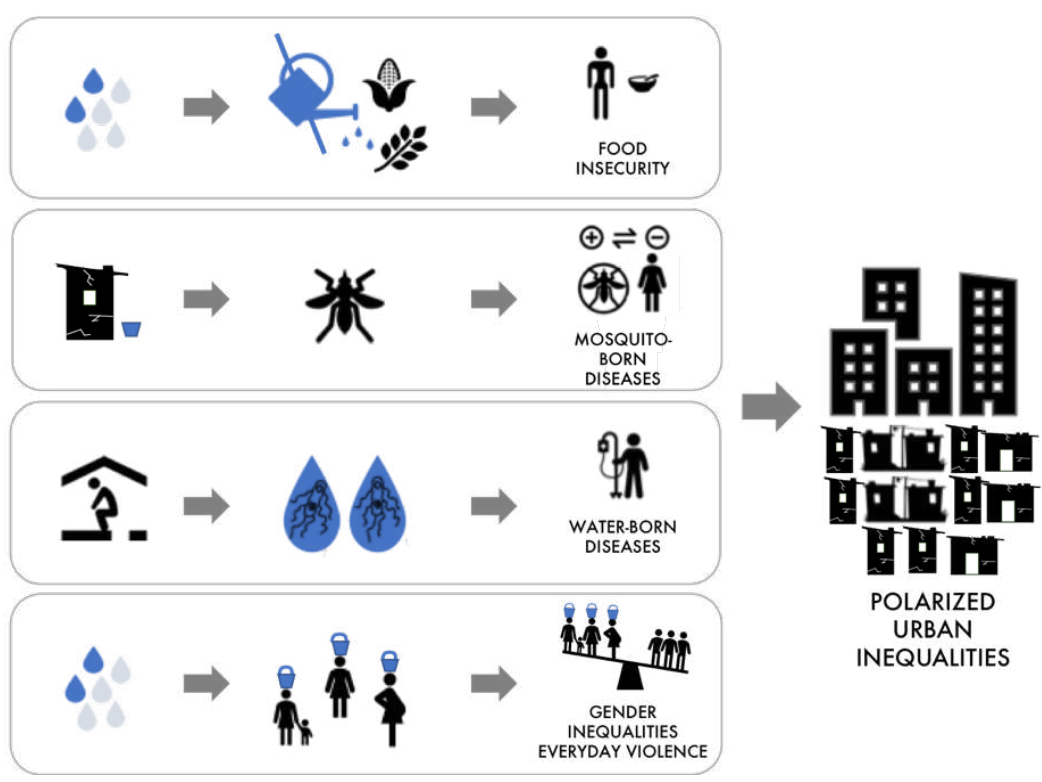

447

448 Figure 3 Cascading effect of water shortages on other urban inequalities. Acute water shortages,

449 which will mostly affect residents in low-income areas, generate or exacerbate food insecurity,

450 mosquito-borne and water-borne diseases, as well as gendered inequalities. 
454 The Social-Environmental Extremes Scenario Approach is grounded on: a synergy of critical

455 social science theoretical perspectives on multiscalar societal responses to extreme events

456 (Pillar 1); literature-based climate projections identifying plausible areas at risk of unprecedented extreme occurrences (Pillar 2); empirical research on past socialenvironmental extremes in the location of interest (Pillar 3) and in other locations to examine events of greater magnitude than those observed at the location of interest (Pillar 4) (see

460 Figure $\mathrm{S} 1)^{1}$. In this study, we focus on droughts as extreme event of interest. Maputo (i.e. the 461 location of interest - Pillar 3) and Cape Town (i.e. conceptual transfer - Pillar 4) were chosen as instrumental case studies because both cities were recently affected by a drought, share several historical legacy and social characteristics and Maputo is likely to experience unprecedented drought events in the future (Pillar 2). Empirical analyses of past events in

465 Maputo and Cape Town were conducted through mixed method approaches (see Pillar 3 and

466 Pillar 4). Below, we provide a detailed outline of Pillars 1-4, from which we develop the

467 Social-Environmental Extremes Scenario of unprecedented drought in Maputo, Mozambique.

\section{Pillar 1 - Societal responses to drought events: a theoretical synthesis}

470 For this study, the theoretical synthesis has examined three interrelated multiscalar components of societal responses to urban droughts: household responses and intersectional

472 dimensions of inequality; the power relations generating drought-induced urban water 473 shortages and the uneven distribution of costs and benefits thereof (i.e. production of water scarcity); and state-civil society relations during and in the aftermath of a severe urban drought (i.e. transformative potential). Figure S2 maps the case studies examined in the

476 theoretical synthesis and Table S1 provides a summary of the phenomena, locations and 
authors of the research. Last, Table S2 provides a synthetic overview of the main findings of

478 the review.

479

480 Pillar 2: Climatic Projection - Southern Africa, Maputo

481 There are a number of regions which have historically been drought-prone and that are

482 projected to become "drought hotspots" under future climates ${ }^{56}$. In the context of our impacts-based focus on urban droughts, an additional relevant criterion was to identify large urban areas vulnerable to water scarcity, and affected by unequal access to water. Southern Africa represents a "perfect storm" coincidence between these different aspects, being a region currently subject to droughts, projected to experience more severe droughts in the future (see "Maputo is likely to face unprecedented droughts") and having rapidly growing urban agglomerates characterised by large socio-economic inequalities. Cape Town is a natural choice for Pillar 4, having been widely reported as the first major city to be near the

490 "day zero" no-water scenario ${ }^{57}$. Maputo, on the other hand, has experienced severe droughts 491 in the recent past, but in comparison has received scant attention by the media and scientific community. However, it shares Cape Town's vulnerability to water scarcity, large inequalities, a segregated urban form, and additionally has unevenly developed water supply infrastructure ${ }^{43,58,59}$. As such, it is a highly relevant case study on which to build a socioenvironmental scenario of future, unprecedented drought.

496 There is no single definition of drought from a physical-environmental perspective. The 497 sources used in our analysis (see "Maputo is likely to face unprecedented droughts") adopt different definitions, generally including some measure of precipitation deficit and optionally

499 additional factors such as estimates of evapotranspiration. For Fig. S3, we have opted to use 500 the Standardized Precipitation Evapotranspiration Index (SPEI), from the SPEIbase dataset, 501 which considers a climatic water balance including the effects of temperature and 
evapotranspiration at multiple temporal scales. This index was specifically designed to

503 explore the impacts of global warming on drought ${ }^{60,61}$. The figure illustrates the severity of

504 the recent drought in Cape Town (thin blue curve), which peaked between 2015 and 2017 ,

505 and the less hydroclimatically severe but nonetheless impacting drought in Maputo (thin red

506 curve), peaking in 2016-2017. While remote precipitation may affect the water resources of

507 these cities through rivers feeding into reservoirs, and consumption patterns can also play a

508 large role, we note that the drought periods evidenced by the SPEI index mostly reflect the

509 periods of reported water shortage. For example, in Cape Town the highest level of

510 restrictions was in place between January and October 2018, with the former date closely

511 following both the minimum SPEI value and the minimum reservoir water levels (thick blue

512 curve). In Maputo, water restrictions were put in place in early 2017. A short recovery of the

513 SPEI value to wet conditions during 2017 was not followed by a corresponding increase in

514 reservoir levels (thick red curve), plausibly because adjacent regions to the South and West of

515 Maputo continued to have negative SPEI values. A regional analysis of the SPEI data further

516 shows that Maputo and the surrounding regions have been a regional epicentre for drought

517 episodes over the last 5 decades, typically showing SPEI values in line with or lower than

518 other locations within a roughly $1000 \mathrm{~km}$ radius during drought periods (not shown).

Pillar 3: Societal responses to the 2016-2018 drought in Maputo

521 In Maputo, qualitative data were collected through 65 semi-structured interviews undertaken

522 between November 2013 and February 2014, November and December 2016, and August

523 and November 2017 and a videography project undertaken in August 2017. Follow up

524 interviews were conducted in May-June 2021. Interviews were held with national and local

525 public health and water sector organization, municipal authorities, consultants, water

526 providers (AdeM and Small-Scale Independent Providers) and the national water regulator, as 
well as with residents in low-income areas and local authorities. A drinking water quality

528 sampling campaign was carried out between December 2016 and September 2017 to examine

529 water quality across high and low income neighborhoods and risks of waterborne diseases.

530 This data was triangulated with a documentary analysis of drinking water and sanitation

531 policies.

\section{Household responses and intersectionality}

534 The impacts of the drought in Maputo were spatially variegated. First, the households served

535 by the public water utility (approximately $64 \%$ of the urban population), were significantly

536 more affected than those served by small-scale water providers (approximately 33-34 \% of

537 the urban population). The water utility AdeRM relies on surface water from the Umbeluzi

538 river, which is stored in the Pequenos Libombos dam and supplies 98\% of the Maputo's

539 residents connected to the centralized network. Small-scale providers (SSIPs), on the other

540 hand, abstract (sometimes treat) and distribute groundwater through decentralized networks.

541 In January 2017, the water reserves of the Pequenos Libombos dam, reached an alarming

$54216 \%{ }^{64}$. In contrast, in areas served by SSIPs, groundwater worked as a buffer, but increased

543 abstraction rates have exacerbated salt water intrusion in coastal areas ${ }^{65}$. This raised questions

544 on the long-term sustainability of this service modality.

545 Second, the restrictions introduced by the water utility Águas da Região de Maputo (AdeM)

546 in response to the water shortage affected lower income residents significantly more than

547 affluent ones (see also Pillar 1 and 4). Neighborhoods at the margins of the water supply

548 network experienced much longer and intense shortages than those centrally located. Some

549 only received water twice a week, others experienced water shortages for over three weeks,

550 and some only had water at night. Despite this, residents continued to be billed and charged

551 for regular water consumption, and threatened disconnection in case of non-payment. The 
552 drought is exemplary of the uneven impact of reduced water availability across intra-urban

553 spaces. With increased water shortages, storage facilities became the most essential coping

554 strategy. Whilst higher income residents could rely on a higher storage capacity (500 to 1500

555 L) to cope with water rationing measures, mid and low-income neighborhoods had to make

556 due with 200-250 L to $1.5 \mathrm{~L}$ containers. Additionally, affluent households that were already

557 less affected by water rationing measures were able to integrate their supply with private

558 wells, boreholes and bottled water.

559 Third, water shortages in low income areas generated or exacerbated existing gendered and

560 well-being inequalities. Women in charge of water-intense domestic chores (cleaning,

561 cooking, doing laundry) had to fetch water from boreholes or better served neighborhoods.

562 As a result, they often missed work or had to wake up at night to do laundry and store some

563 water for the day. These coping practices increase women's water labour and stress, as well

564 as everyday risks of violence for women having to collect water at night ${ }^{66}$. Last, the drought

565 also had several negative health implications, especially for low-income dwellers. There is a

566 strong correlation between urban poverty and the use of on-site sanitation. In areas

567 characterized by significant sanitation infrastructure and services deficits, especially those

568 that are flood prone, water stress coalesced with poor sanitation and urban flash floods

569 producing high risk of fecal contamination of water and, in turn, diarrheal diseases ${ }^{43}$. This

570 resulted in a cholera outbreak, concentrated in poorly served neighborhoods. Moreover,

571 uncovered containers located in proximity to humans, frequently found in lower income

572 households, formed suitable habitats for Aedes aegypti vectors of chikungunya, dengue, and

573 zika diseases ${ }^{67}$.

$574 \quad$ Producing water scarcity

575 Differentiated levels of water shortages are generated by the uneven development trajectory

576 of Maputo. Maputo's trajectory was and continues to be shaped by ideas of differentiated 
citizenship across identities and socio-economic groups, and is reflected in heterogeneous

578 infrastructure and services developments ${ }^{43}$. The colonial state, grounded on principles of

579 racial superiority, developed a segregationist spatial order in which colonial elites and the

580 assimilated population accessed advanced centralized water and sanitation services, whilst

581 natives were excluded ${ }^{58,59,68}$. Following independence, the Mozambican state embraced

582 principles of inclusive development, but largely reproduced existing inequalities. Limited

583 investment in network expansion and the civil war (1977-1992) constrained progress on

584 water and sanitation. The past decade, was marked by a significant increase in water

585 coverage. Reduced connection fees and installment payments for water meters attracted lower

586 income residents, leading to the doubling water connections between 2009 and $2017^{69}$.

587 Today, approximately $64 \%$ of the population is connected to the centralized water supply

588 network. The drought, however, has shown that coverage does not always entail access:

589 increased coverage resulted in reduced availability as the Corumana Dam project to increase

590 supply was not completed before the drought. Moreover, water shortages exacerbated

591 inequalities embedded in the technical characteristics of the network and in the spatial

592 distribution of reservoirs. As noted for other postcolonial cities (Pillar 1), the network in

593 Maputo prioritizes the city center by design. The distribution centers are concentrated in the

594 proximity of the city center and, in times of water rationing, water distributed from the center

595 to the periphery, was mostly consumed by higher income neighborhoods, who also relied on

596 larger storage facilities ${ }^{43}$.

597 Transformative potential

598 As suggested in Pillar 1 and 4, the drought turned into a market opportunity for existing and

599 emerging profit-oriented providers. SSIPs were able to increase their market share, with

600 many households connected to the water utility and located in proximity to private systems,

601 opted for a second connection to augment supply. Other profit-oriented initiatives included 
water resale from boreholes or better served in-house connection, and water tankers.

603 Moreover, in 2021 the Ministry of Infrastructures announced an effort to create the conditions

604 for greater private sector participation in water service provision in Greater Maputo ${ }^{70}$. This

605 initiative is linked to the overall strategy of the government in response to the drought, which

606 is largely prioritized incrementing supplies over water conservation.

607 Water conservation measures were limited to public campaigns on how to save water (e.g.

608 avoid using drinking water to clean, water lawns and washing cars, using buckets rather than

609 showers) rather than sanctioned restrictions. In contrast, incrementing water supplies was and

610 remains the main short- and long-term strategy. This strategy was promoted by discursively

611 framing the drought as natural and water shortages as a problem to be addressed by

612 incrementing supplies. In line with this narrative, the emergency strategy focused on

613 developing groundwater resources and reactivating existing boreholes, whilst the mid and

614 long-term approach focused on large dams, including a number of current (Corumana,

615 Moamba) and new (Tembe, Tre Fronteiras, Movene) dam development projects, treatment

616 facilities (Sabié), groundwater exploitation, and desalination. Although the hidden debt crisis

617 slowed down the implementation of these plans, in 2021 the Sabié treatment facility and new

618 distribution centers funded by the World Bank have been completed. The subsequent network

619 expansion has generated significant tensions and conflicts with SSIPs that are losing market

620 shares and their capital investment ${ }^{70}$.

621 Last, during the emergency households facing extensive water shortages focused on everyday

622 practices to access water rather than on collective action for just transformations. In some

623 neighborhoods, however, residents have mobilized to collectively divert water from the main

624 pipes supplying better served neighborhoods to theirs. Similar practices were performed

625 individually by households in other neighborhoods. Whilst the water utility interpreted this as 
acts of vandalism that severely affect the network, residents claimed this is their only way to

627 access water.

628

629 Pillar 4: Societal responses to the 2015-2017 drought in Cape Town

630 In Cape Town, qualitative data were collected between May 2019 and March 2020 through

63165 semi-structured interviews and 5 focus group discussions with households, and

632 governmental and non-governmental water sector organisations. The interview investigated

633 Capetonians' intersectional dimensions of vulnerability and their heterogeneous responses to

634 the drought. Data were triangulated with media outlets and reports. Quantitative data

635 including time series of rainfall, reservoir storage, human population, and daily water

636 consumption, have been retrieved from the City of Cape Town Data portal. Information on

637 the physical characteristics of past and future droughts was retrieved from the recent

638 academic literature and from the SPEIbase drought dataset ${ }^{60,61}$.

639

$640 \quad$ Household responses and intersectionality

641 In response to a severe meteorological drought which lasted from 2015 until 2017, the Water

642 System of Cape Town's metropolitan area dried up almost completely. Shortly after, the City

643 plunged into an unprecedented water crisis widely known as Day Zero. On the 18th of

644 January 2018, the Municipality of Cape Town introduced severe water restrictions and

645 demand management measures to avoid Day Zero, the moment in which the City would run

646 out of water. In line with findings from Pillar 1, these measures -encompassing water

647 rationing of 50 liters/person/day for a maximum of 350 liters/unit/day, increased tariffs,

648 overconsumption fines and installation of metering devices to enforce compliance- affected

649 lower-income and minority groups the most. 
650 Affluent households that were used to consuming up to 8560 liters per day, had to

651 significantly reduce their consumption and give up irrigating lawns, washing cars and filling

652 their swimming pools, Yet, they did not suffer from shortages. These households were largely

653 unaffected by the tariff increases and fines, and were able to access or quickly resort to

654 alternative water sources, such as bottled water, rainwater and groundwater, and substantially

655 increase their water availability. Conversely, the same restrictions are described as "a shock"

656 by townships residents and working-class households who could not afford the increases in

657 tariff, the fines nor the costs of accessing or developing alternative water sources. Moreover,

658 in low-income areas it is common for more than one household to share one housing unit.

659 These housing units, therefore, had to share the allocated 350 liters among up to 15 people.

660 Last, low-income we most of the metering devices that halted the consumption of water at

661350 liters/unit/day, were installed in lower-income households ${ }^{8,71,72}$. Many women living in

662 these areas faced a considerable amount of stress every time the metering device interrupted

663 the water provision in the middle of the day. Without relying on any alternative, these women

664 had to give up on washing their clothes, cleaning the house or cooking the family meal ${ }^{8}$.

665 Uneven water insecurity levels across intra-urban spaces and socio-technical measures

666 enforced by the municipality generated different recovery trajectories across the city. In low-

667 income neighborhoods, many households continue to struggle in the aftermath of the drought,

668 due to the increased water tariffs and the rationing imposed through water metering devices.

669 Conversely, higher income residents enhanced their resilience to future droughts by investing

670 in alternative water sources. In fact, the reduction of the City's water demand from 1000 to

671500 Million Liters per/day is attributable to larger consumers going off the grid rather than to

672 actual reductions in consumption ${ }^{73}$.

673 Producing water scarcity 
674 The uneven experience of the drought reflects unequal water (in)securities engendered by

675 colonial legacies, racialized segregation and neoliberal reforms which over time have

676 produced spaces of inequalities and unsustainable water consumption ${ }^{8,71,72}$. The water supply

677 expansion strategy pursued by the Apartheid and post-apartheid government set in motion a

678 vicious cycle of incremental water use by Capetonian elites and incremental infrastructural

679 development, which overlooked environmental and social sustainability concerns,

680 exacerbating the city's vulnerability to water shortages and droughts ${ }^{8}$.

681

682 Transformative potential

683 The water crisis generated both possibilities for progressive transformations and new forms

684 of water commodification ${ }^{72}$. The fact that measures such as increased water tariffs are still in

685 place is proof of such commodification. In addition, the City withdrew the universal

686 provision of the first 6 kiloliters of free basic water by making it conditional to the

687 registration of residents as indigents. Moreover, low income residents continue to experience

688 water rationing as a result of the metering devices that limit supply to 350 liters per day. At

689 the same time, the crisis has reinvigorated the City's propension to supply expansion, now

690 directed to desalination and groundwater exploitation.

691 At the same time, the government's response to the crisis ignited a strong opposition from

692 those most affected by the drought and the subsequent measures. The struggle for water

693 became enmeshed with broader struggles and claims of citizenship ${ }^{71,74}$, led by well-

694 established grassroots organizations, such as Environmental Monitoring Group (EMG), and

695 emerging initiatives such as the Water Crisis Coalition (WCC). Trade unions, and activists

696 coalesced to protest water tariffs and restrictions whilst advancing a wider political stand

697 against water privatization and neoliberal policies ${ }^{74}$. Moreover, campaigns that were

698 (re)reframed around water conservation gained momentum, and succeeded in protecting 
699 farming land (and Cape Flats Aquifer) from rezoning ${ }^{75}$ and in reclaiming water springs from 700 South African Breweries ${ }^{71}$.

701 
M.R. and G.M. conceived the study. The writing of the manuscript was led by M.R. with substantive input from G.M. and E.S. Fieldwork in Maputo and data analysis was conducted by M.R. with substantial contribution by A.B., whilst field work in and data analysis of Cape town was undertaken by E. S. Tables and graphs have been developed by G.M., E.S., M.R and G.D.B. and final editing has been done by all authors.

708

709

\section{Competing interests}

710 The authors declare no competing interests.

711

712

Additional information

713 No additional information. 
716 1. Rusca, M., Messori, G. \& Di Baldassarre, G. Scenarios of human responses to

717 unprecedented social-environmental extreme events. Earths Future 9, e2020EF001911

$718 \quad(2021)$.

719 2. Musemwa, M. Coping with water scarcity: The social and environmental impact of 720 the1982-1992 droughts on Makokoba Township, Bulawayo, Zimbabwe. in African Cities $721 \quad$ 157-185 (Brill, 2009).

722 3. Kaika, M. Constructing scarcity and sensationalising water politics: 170 days that shook $723 \quad$ Athens. Antipode 35, 919-954 (2003).

724 4. Satur, P. \& Lindsay, J. Social inequality and water use in Australian cities: the social 725 gradient in domestic water use. Local Environ. 25, 351-364 (2020).

726 5. March, H. \& Sauri, D. When sustainable may not mean just: a critical interpretation of 727 urban water consumption decline in Barcelona. Local Environ. 22, 523-535 (2017).

728 6. Rusca, M., Alda-Vidal, C., Hordijk, M. \& Kral, N. Bathing without water, and other 729 stories of everyday hygiene practices and risk perception in urban low-income areas: The $730 \quad$ case of Lilongwe, Malawi. Environ. Urban. 29, 533-550 (2017).

731 7. Rusca, M., Boakye-Ansah, A. S., Loftus, A., Ferrero, G. \& Van Der Zaag, P. An 732 interdisciplinary political ecology of drinking water quality. Exploring socio-ecological 733 inequalities in Lilongwe's water supply network. Geoforum 84, 138-146 (2017).

734 8. Savelli, E., Rusca, M., Cloke, H. \& Di Baldassarre, G. Don’t blame the rain: Social 735 power and the 2015-2017 drought in Cape Town. J. Hydrol. 125953 (2021) 736 doi:10.1016/j.jhydrol.2020.125953.

737 9. Truelove, Y. (Re-) Conceptualizing water inequality in Delhi, India through a feminist 738 political ecology framework. Geoforum 42, 143-152 (2011). 
10. Anand, N. Hydraulic City: Water and the Infrastructures of Citizenship in Mumbai.

$740 \quad$ (Duke University Press, 2017).

741 11. Brewis, A. et al. Community hygiene norm violators are consistently stigmatized:

742 Evidence from four global sites and implications for sanitation interventions. Soc. Sci.

$743 \quad$ Med. 220, 12-21 (2019).

744 12. Sultana, F. Gendered Waters, Poisoned Wells: Political Ecology of the Arsenic Crisis in 745 Bangladesh. Fluid Bonds Views Gend. Water (2006).

746 13. Sultana, F. Fluid lives: subjectivities, gender and water in rural Bangladesh. Gend. Place Cult. 16, 427-444 (2009).

14. Harris, L., Kleiber, D., Goldin, J., Darkwah, A. \& Morinville, C. Intersections of gender and water: comparative approaches to everyday gendered negotiations of water access in

16. Brewis, A., Workman, C., Wutich, A., Jepson, W. \& Young, S. Household water

17. Young, S. L. et al. The Household Water InSecurity Experiences (HWISE) Scale: development and validation of a household water insecurity measure for low-income and middle-income countries. BMJ Glob. Health 4, e001750 (2019). Household Food Insecurity during and after a Drought in the District of iLembe, South Africa. Ecol. Food Nutr. 60, 25-43 (2021). 
19. Swyngedouw, E. Power, nature, and the city. The conquest of water and the political ecology of urbanization in Guayaquil, Ecuador: 1880-1990. Environ. Plan. A 29, 311332 (1997).

20. Giglioli, I. \& Swyngedouw, E. Let's drink to the great thirst! Water and the politics of fractured techno-natures in Sicily. Int. J. Urban Reg. Res. 32, 392-414 (2008).

21. Tiwale, S., Rusca, M. \& Zwarteveen, M. The power of pipes: Mapping urban water inequities through the material properties of networked water infrastructures-The case of Lilongwe, Malawi. Water Altern. 11, 314-335 (2018).

22. Björkman, L. Pipe politics, contested waters. (Duke University Press, 2015).

23. Millington, N. Producing water scarcity in São Paulo, Brazil: The 2014-2015 water crisis and the binding politics of infrastructure. Polit. Geogr. 65, 26-34 (2018).

24. Schwartz, K., Tutusaus Luque, M., Rusca, M. \& Ahlers, R. (In) formality: the meshwork of water service provisioning. Wiley Interdiscip. Rev. Water 2, 31-36 (2015).

25. Ahlers, R., Perez Güida, V., Rusca, M. \& Schwartz, K. Unleashing entrepreneurs or controlling unruly providers? The formalisation of small-scale water providers in Greater Maputo, Mozambique. J. Dev. Stud. 49, 470-482 (2013).

26. Pihljak, L. H., Rusca, M., Alda-Vidal, C. \& Schwartz, K. Everyday practices in the production of uneven water pricing regimes in Lilongwe, Malawi. Environ. Plan. C Polit. Space 2399654419856021 (2019) doi:10.1177/2399654419856021.

27. Vitz, M. A City on a Lake. (Duke University Press, 2018).

28. Kallis, G. \& Coccossis, H. Managing water for Athens: from the hydraulic to the rational growth paradigm. Eur. Plan. Stud. 11, 245-261 (2003).

29. Nevarez, L. Just Wait Until There's a Drought: Mediating Environmental Crises for Urban Growth. Antipode 28, 246-272 (1996). 
30. Tomaz, P., Jepson, W. \& Santos, J. de O. Urban Household Water Insecurity from the Margins: Perspectives from Northeast Brazil. Prof. Geogr. 72, 481-498 (2020).

31. Bakker, K. J. Privatizing water, producing scarcity: The Yorkshire drought of 1995. Econ. Geogr. 76, 4-27 (2000).

32. Ozan, L. A. \& Alsharif, K. A. The effectiveness of water irrigation policies for residential turfgrass. Land Use Policy 31, 378-384 (2013).

33. Saurií, D. Lights and Shadows of Urban Water Demand Management: The Case of the Metropolitan Region of Barcelona. Eur. Plan. Stud. 11, 229-243 (2003).

34. Albiac, J., Hanemann, M., Calatrava, J., Uche, J. \& Tapia, J. The rise and fall of the Ebro water transfer. Nat. Resour. J. 727-757 (2006).

35. Jaffee, D. \& Case, R. A. Draining us dry: Scarcity discourses in contention over bottled water extraction. Local Environ. 23, 485-501 (2018).

36. Cohen, D. A. The rationed city: The politics of water, housing, and land use in droughtparched São Paulo. Public Cult. 28, 261-289 (2016).

37. Breyer, B., Zipper, S. C. \& Qiu, J. Sociohydrological Impacts of Water Conservation Under Anthropogenic Drought in Austin, TX (USA). Water Resour. Res. 54, 3062-3080 (2018).

38. Hackman, R. California drought shaming takes on a class-conscious edge. the Guardian (2015).

39. Milbrandt, T. Caught on camera, posted online: mediated moralities, visual politics and the case of urban 'drought-shaming'. Vis. Stud. 32, 3-23 (2017).

40. Grasham, C. F., Korzenevica, M. \& Charles, K. J. On considering climate resilience in urban water security: A review of the vulnerability of the urban poor in sub-Saharan

$811 \quad$ Africa. Wiley Interdiscip. Rev. Water 6, e1344 (2019). 
812 41. Wutich, A. \& Ragsdale, K. Water insecurity and emotional distress: coping with supply,

813 access, and seasonal variability of water in a Bolivian squatter settlement. Soc. Sci. Med. $814 \quad 1982$ 67, 2116-2125 (2008).

815 42. Mehta, L. Whose scarcity? Whose property? The case of water in western India. Land $816 \quad$ Use Policy 24, 654-663 (2007).

817 43. Rusca, M. et al. The Urban Metabolism of Waterborne Diseases: Variegated Citizenship, 818 (Waste) Water Flows, and Climatic Variability in Maputo, Mozambique. Ann. Am. Assoc. 819 Geogr. 1-20 (2021).

820 44. Alda-Vidal, C., Kooy, M. \& Rusca, M. Mapping operation and maintenance: An 821 everyday urbanism analysis of inequalities within piped water supply in Lilongwe, $822 \quad$ Malawi. Urban Geogr. 39, 104-121 (2018).

823 45. Anand, N. Municipal disconnect: On abject water and its urban infrastructures. Ethnography 13, 487-509 (2012).

825 46. Anand, N. PRESSURE: The PoliTechnics of Water Supply in Mumbai. Cult. Anthropol. $826 \quad 26,542-564(2011)$.

47. Austin, K. F., Noble, M. D. \& Berndt, V. K. Drying Climates and Gendered Suffering: Links Between Drought, Food Insecurity, and Women's HIV in Less-Developed Countries. Soc. Indic. Res. 154, 313-334 (2021).

48. Chitonge, H. Cities Beyond Networks: The Status of Water Services for the Urban Poor in African Cities. Afr. Stud. 73, 58-83 (2014).

49. Millington, N. Producing water scarcity in São Paulo, Brazil: The 2014-2015 water crisis and the binding politics of infrastructure. Polit. Geogr. 65, 26-34 (2018).

834 50. Taylor, V., Chappells, H., Medd, W. \& Trentmann, F. Drought is normal: the socio835 technical evolution of drought and water demand in England and Wales, 1893-2006. J.

836 Hist. Geogr. 35, 568-591 (2009). 
837 51. Kallis, G. Droughts. Annu. Rev. Environ. Resour. 33, 85-118 (2008).

838 52. Heynen, N., Kaika, M. \& Swyngedouw, E. In the nature of cities: urban political ecology

839 and the politics of urban metabolism. vol. 3 (Taylor \& Francis, 2006).

840 53. Rusca, M. \& Schwartz, K. The paradox of cost recovery in heterogeneous municipal

841 water supply systems: ensuring inclusiveness or exacerbating inequalities? Habitat Int.

$842 \quad 73,101-108(2018)$.

843 54. Kimari, W. \& Ernstson, H. Imperial Remains and Imperial Invitations: Centering Race

844 within the Contemporary Large-Scale Infrastructures of East Africa. Antipode 52, 825-

$845 \quad 846(2020)$.

846 55. Bakker, K. Neoliberalizing Nature? Market Environmentalism in Water Supply in

847 England and Wales. Ann. Assoc. Am. Geogr. 95, 542-565 (2005).

848 56. Lu, J., Carbone, G. J. \& Grego, J. M. Uncertainty and hotspots in 21 st century projections

849 of agricultural drought from CMIP5 models. Sci. Rep. 9, 1-12 (2019).

850 57. Maxmen, A. As Cape Town water crisis deepens, scientists prepare for 'Day Zero'.

$851 \quad$ Nature 554, 13-14 (2018).

852 58. Biza, A., Kooy, M., Manuel, S. \& Zwarteveen, M. Sanitary governmentalities: Producing

853 and naturalizing social differentiation in Maputo City, Mozambique (1887-2017).

854 Environ. Plan. E Nat. Space 2514848621996583 (2021)

855 doi:10.1177/2514848621996583.

856 59. Jenkins, P. City profile: Maputo. Cities 17, 207-218 (2000).

857 60. Vicente-Serrano, S. M., Beguería, S. \& López-Moreno, J. I. A Multiscalar Drought Index

858 Sensitive to Global Warming: The Standardized Precipitation Evapotranspiration Index.

$859 \quad$ J. Clim. 23, 1696-1718 (2010).

860 61. Vicente-Serrano, S. M., Beguería, S., López-Moreno, J. I., Angulo, M. \& El Kenawy, A.

861 A new global 0.5 gridded dataset (1901-2006) of a multiscalar drought index: 
comparison with current drought index datasets based on the Palmer Drought Severity Index. J. Hydrometeorol. 11, 1033-1043 (2010).

62. CSAG. The Big Six Monitor Database from the Climate System Analysis Group CSAG. https://cip.csag.uct.ac.za/monitoring/bigsix.html (https://cip.csag.uct.ac.za/monitoring/bigsix.html z).

63. Notisso, P. F. Aplicação do modelo weap na avaliação de alocação de água Do reservatório dos pequenos libombos, moçambique. (Universidade Federal de Goiás, 20AD).

64. AdP. Medidas a implementar para minimização dos impactos da falta de água no sistema de abastecimento de água à Área Metropolitana de Maputo no âmbito da missão técnica da ADP a Maputo. (2017).

65. AdeRM. Boletim Infromativo. (2018).

66. Rusca, M. Visualizing urban inequalities: The ethics of videography and documentary

67. Bayona-Valderrama, A., Acevedo-Guerrero, T. \& Artur, C. Cities with Mosquitoes: A filmmaking in water research. Wiley Interdiscip. Rev. Water 5, e1292 (2018). Political Ecology of Aedes Aegypti’s Habitats. Water Altern. 14, 186-203 (2021).

68. Rusca, M. et al. Space, state-building and the hydraulic mission: Crafting the Mozambican state. Environ. Plan. C Polit. Space 37, 868-888 (2019).

69. Zuin, V. \& Nicholson, M. The Impact of Pro-Poor Reforms on Consumers and the Water

882 70. CDD, C. para D. e D. Governo sufoca fornecedores privados que garantiram água por 883 muitos anos nos bairros de expansão do Grande Maputo. Política Moçambicana vol. $884 \quad$ Year $3(2021)$. 
885 71. Robins, S. 'Day Zero', Hydraulic Citizenship and the Defence of the Commons in Cape

886 Town: A Case Study of the Politics of Water and its Infrastructures (2017-2018). J.

$887 \quad$ South. Afr. Stud. 45, 5-29 (2019).

888 72. Scheba, S. \& Millington, N. Crisis temporalities: Intersections between infrastructure and 889 inequality in the Cape Town Water Crisis. Int. J. Urban Reg. Res. (2018).

890 73. WWF. Cape Town's groundwater under the spotlight.

891 https://africa.panda.org/?32522/Cape-Towns-groundwater-under-the-spotlight (2020).

892 74. Peñaloza, R. A. \& Alzaté González, Laura Daniela. Day Zero: the role of social

893 movements in the face of Cape Town's water crisis. (Linnaeus University Master Thesis, 894 2019).

895 75. Ellis, E. Maverick Citizen: Victory in court for Philippi Horticultural Area. Daily

896 Maverick https://www.dailymaverick.co.za/article/2020-02-18-victory-in-court-for-

897 philippi-horticultural-area/ (2020).

898

899 
900 Tables

901

902

903

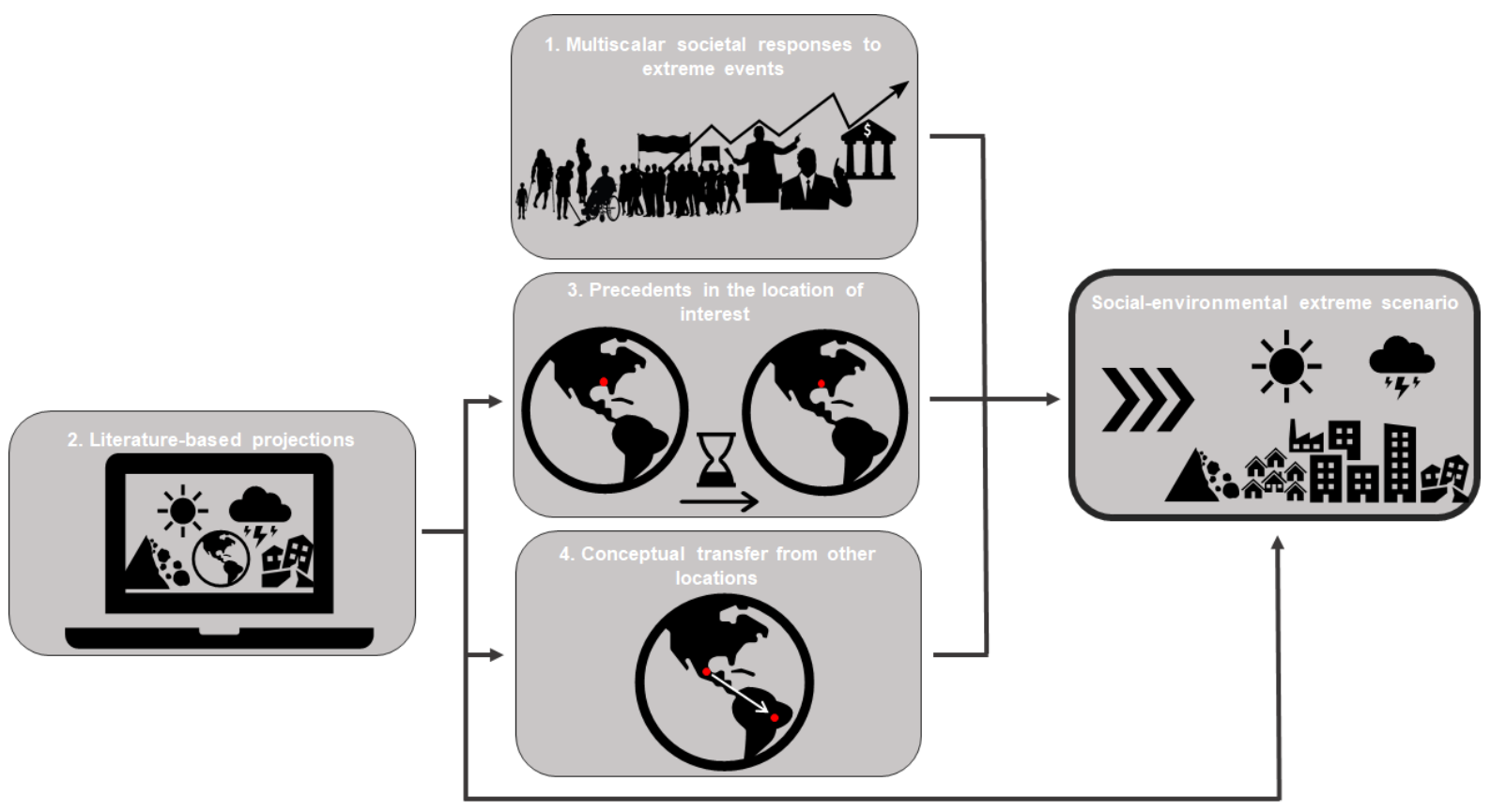

904 Figure S1 Schematic of the Social-Environmental Extremes Scenarios Approach ${ }^{l}$.

905

906 


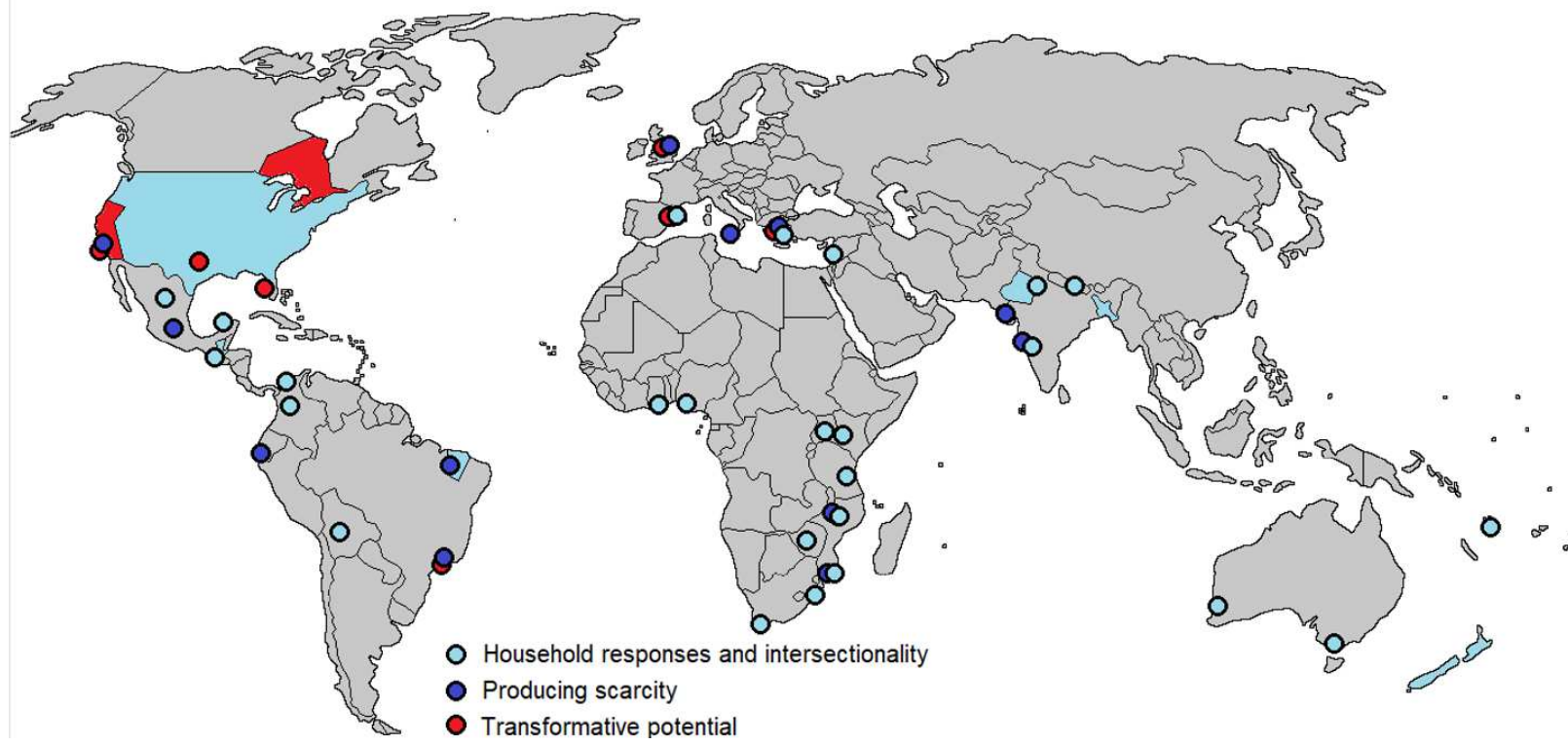

908 Figure S2 Map of the case studies examined for the Theoretical Synthesis (Pillar 1).

\section{THEORETICAL EXPLANATIONS}

AUTHORS

\begin{tabular}{l} 
Vulnerability mediates the impacts of the drought on different social groups and individuals \\
\hline Vulnerability differs across intra-urban spaces, identities (e.g. gender, race), and income groups \\
\hline Vulnerability is tied to the levels of water (in)security experienced before the event \\
\hline Water (in)security is also experienced by residents connected to the centralised water supply network \\
\hline Water shortages have a cascading effect on other urban inequalities (health, safety, food security) \\
\hline Water shortages have a cascading effect on gender inequalities \\
\hline Water rationing and demand management measures exacerbate inequalities in access to water
\end{tabular}

All

THEORETICAL EXPLANATIONS

Droughts are generated by combined physical and human-produced water scarcity Uneven, exclusionary development trajectories determine unequal impacts of the drought

Colonial segregation, racial capitalism, patriarchy shape uneven drought impacts

$42,50,51$

Water (in)security is generated by investment priorities, housing policies, market-based water pricing regimes

\section{THEORETICAL EXPLANATIONS}

$\overline{\text { AUTHORS }}$

Droughts are framed as a natural and unpredictable, deflecting attention from political responsibility

Framing nature as the problem generates consent for unlimited infrastructure development and consumption

Demand management measures can pave the way to managerial approaches and privatization of water utilities

Drought generates new coalitions and trigger multiple moral claims on water beyond its economic value

Droughts intensify protests against the privatization and bottled water

Powerful and affluent residents often contest and do not comply with water restriction

Social pressure is exerted on overconsuming users to reduce their use during droughts

910 Table S1 Summary of the phenomena, case study locations on authors of the studies mapped in Figure

911 S2. The Theoretical Synthesis rests on several case studies on household responses to drought events

912 and intersectionality, the construction of drought disasters and the transformative potential of

913 drought events. 


\section{THEORETICAL EXPLANATIONS}

Vulnerability mediates the impacts of the drought on different social groups and individuals

Vulnerability differs across intra-urban spaces, identities (e.g. gender, race), and income groups

Vulnerability is tied to the levels of water (in)security experienced before the event

Water (in)security is also experienced by residents connected to the centralised water supply network

Water shortages have a cascading effect on other urban inequalities (health, safety, food security)

Water shortages have a cascading effect on gender inequalities

Water rationing and demand management measures exacerbate inequalities in access to water

\section{THEORETICAL EXPLANATIONS}

Droughts are generated by combined physical and human-produced water scarcity Uneven, exclusionary development trajectories determine unequal impacts of the drought

Colonial segregation, racial capitalism, patriarchy shape uneven drought impacts

Water (in)security is generated by investment priorities, housing policies, market-based water pricing regimes

Development-oriented interests, politicians and water providers might profit or politically benefit from droughts

Market-based reforms have increased vulnerability to droughts

Water (in)security is also generated by overconsumption of water by elite users

THEORETICAL EXPLANATIONS

Droughts are framed as a natural and unpredictable, deflecting attention from political responsibility

Framing nature as the problem generates consent for unlimited infrastructure development and consumption

Demand management measures can pave the way to managerial approaches and privatization of water utilities Drought generates new coalitions and trigger multiple moral claims on water beyond its economic value

Droughts intensify protests against the privatization and bottled water

Powerful and affluent residents often contest and do not comply with water restriction

Social pressure is exerted on overconsuming users to reduce their use during droughts

915

916

917 Table S2 Summary of findings of the Theoretical Synthesis. The table outlines the main theoretical

918 findings on: i. Household Responses and Intersectionality; ii. Producing Scarcity; and iii.

919 Transformative Potential of a drought.
AUTHORS

All

$\overline{9,14,15,40,41}$

$3,14,42,43$

$7,9,22,44-46$

$2,18,47$

$6,9,14,15,41$

$6,48,49$

\section{AUTHORS}

$42,50,51$

20,21,51-53

$10,19,27,54$

$21,26,27,36,49$

$3,9,28-30$

31,55

$5,8,21,32,33,42$

AUTHORS

3,29

$3,28,29,31$

28,52

$33,34,36$

35

$28,32,32,37$

38,39 


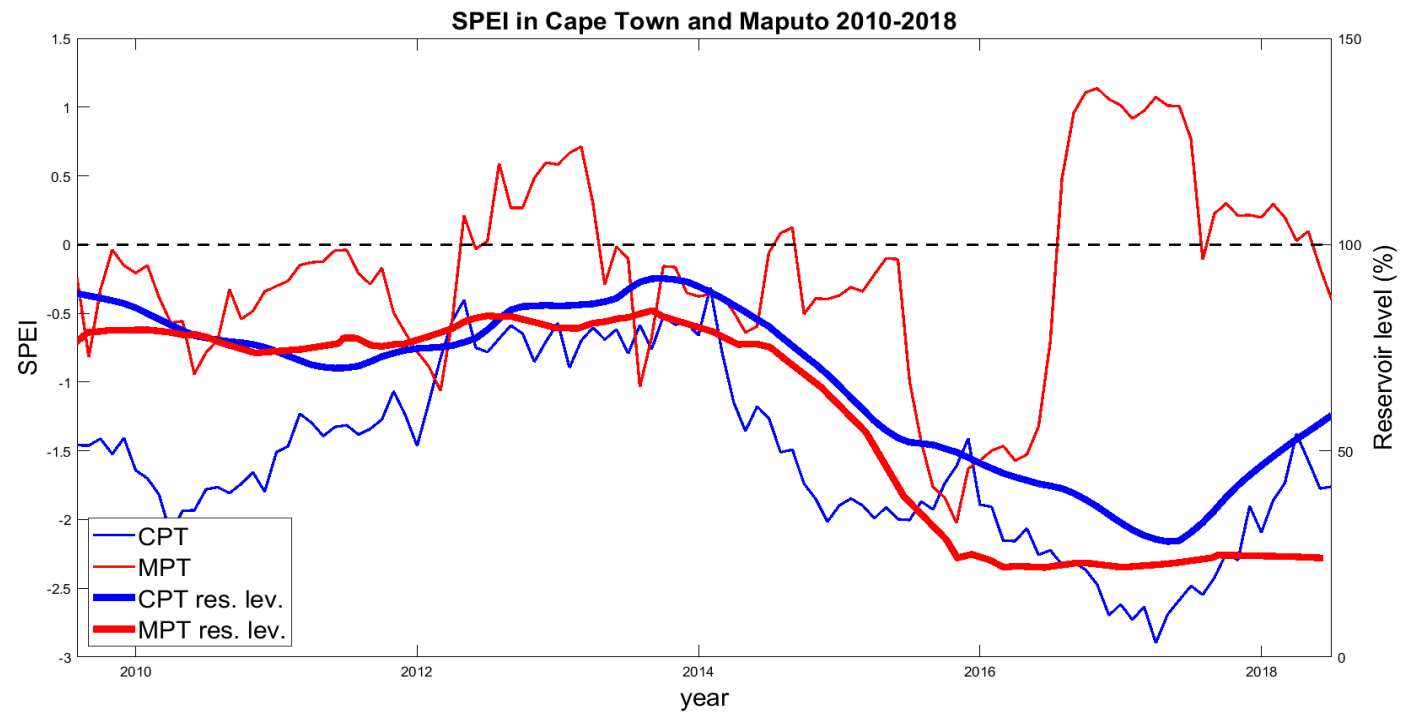

923 Figure S2 12-month SPEI index for the cities of Cape Town (thin blue line) and Maputo (thin red

924 line). The thick lines show the 13-month running mean of filling levels (\%) of the reservoirs supplying

925 Cape Town ${ }^{62}$ and Maputo ${ }^{63}$. The labels on the $x$-axis indicate the center point of each year. 